\title{
Developing STS Circular Motion Unit for Providing Students' Perception of the Relationship between Science Technology Engineering and Mathematics
}

\author{
Prapatsorn Seattha \\ Chokchai Yuenyong* \\ Sitthipon Art-in \\ Faculty of Education, Khon Kaen University, Thailand \\ Email: ychok@kku.ac.th
}

\section{Doi:10.5901/mjss.2015.v6n3s1p268}

\section{Abstract}

STEM education suggested that students should be enhanced to learn science with integration between Science, Technology, Engineering and Mathematics. To help Thai students make sense of relationship between Science, Technology, Engineering and Mathematics, this paper presents learning activities of STS Circular Motion Unit. The developing of STS Circular Motion Unit is a part of research that aimed to enhance students' perception of the relationship between Science Technology Engineering and Mathematics. This paper will discuss how to develop Circular Motion Unit through STS approach in framework of Yuenyong (2006) where learning activities were provided based on 5 stages. These included (1) identification of social issues, (2) identification of potential solutions, (3) need for knowledge, (4) decision-making, and (5) socialization stage. The learning activities could be highlighted as following. First stage, we use video clip of 'Trucks fail to negotiate dangerous bend in road-Brazil'. Second stage, students will need to identification of potential solutions by design safety road. The need of scientific and other knowledge will be proposed for various alternative solutions. Third stage, students will gain their scientific knowledge through laboratory and demonstration of circular motion. Fourth stage, students have to make decision for the best solution of designing safety road based on their scientific knowledge and others (e.g. mathematics, economics, art, value, and so on). Finally, students will present and share their Design Safety Road in society (e.g. social media or exhibition) in order to validate their ideas and redesigning. The paper may have implications for developing science teaching with STEM education.

Keywords: STEM, STS, Circular motion, Technological Process, Engineering Design

\section{Introduction}

Lifelong learning is a prominent public policy theme for many countries and non-governmental organizations for education, economic, political, social and cultural purposes. Education systems are expected to convey values that will help develop more just and inclusive societies; they must also provide a variety of learning experiences to train a competent and active citizenship, and ensure quality and equity in learning outcomes. The goal and vision of the Thai science education suggests that science teaching and learning should lay emphasis on the relationship between science, technology and society; and life-long learning (IPST, 2002). And, the goal also aims to provide students with the intrigued study in Science, Technology, Engineering and Mathematics. So students can use the knowledge in many subjects to solve the problem, research and improve many things in today world. All learning from all teachers is help to solve real problems and very life problems. All those problems need all the knowledge you have, not individual one. (Bernard, 2012; Siripattrachai, 2013)

Introducing students to learn science regarding the integrated concepts of science, technology, engineering and mathematics is rising across the world (Bernard, 2012). According to 21st century citizen decision making, the issues are related to science, technology, engineering, and mathematics. Therefore, STEM Education was recognized. Science is the subject that study from natural phenomena by scientific inquiry.Technology is the subject that applied all the subject to help solve the problems and also improving and developing to human need.Engineering is the subject that creative innovation and build many things to accommodate human by use the knowledge of Science, Mathematics and Technology to inventive.Mathematics is the subject that about calculation at this subject is very important foundation of education. Mathematics can be further in engineering. (Dejarnette, 2012; Bybee, 2010)

The literature suggested many possible activities of STEM Education. These included 1) Integrate Science, Technology, Engineering and Mathematics Content; 2) Link all the Science, 3) Mathematics and Technology to real world; 4) Engage in inquiry; 5) Project base; Apply Technology Strategically; 6) Focus on the skills of the Twenty first 
Century; 7) Building an awareness and participation in the community

1. Integrate Science, Technology, Engineering and Mathematics Content.

Students will learn how to integrate the knowledge in Science, Technology, Engineering and Mathematics, to solve the problem. This guideline will help students to use all the knowledge that they got to solve real life problems.( Bernard J, 2012; Siripattrachai, 2013)

2. Link all the Science, Mathematics andTechnology to real world.

This learning can occur naturally and useful in real life. This is the first integration step, meaningful education. The phenomenon or inventions around us not the only one to learn from but we can use and applied all those knowledge for example calculated the tissue roll, it can link to the suspicion on materials and technology manufacture. This is the process of engineering analysis problem and also helps to inventive in solving problem in many ways.(Lungkhapin, 2013)

3. Engage in inquiry.

This study the students can learn about problems and the setting of the questions and can self explanation by get all the information, communicate and reason to compare the entire concept. So it can determine in the same way, this study is the way that very open for integrated of other knowledge. (Bernard J, 2012) This study is supported by STEM Education. (Lungkhapin, 2013)

4. Project base.

This study will use project base, by using this project base to study its help with integrating and lead to how to solve the problem clearly. This is the right way and the best support of STEM Education. With this project will let students learn from the important real experience of learning in every step of it. It's star from learning the problem, design how to get information, doing it, summary of it and can communicating research. (Lungkhapin, 2013)

5. Apply Technology Strategically.

Students will use the technology to answer the question or solving the problems. This is the way of learning in STEM Education by student will understand technology first, to use it to solve the problem or answer the complex question. Students can improved and create new technology for extend the human capabilities. (Bernard J, 2012) For example : by using photography, VDO, multimedia by using sensor, data logger to record all the information and using the software to search information and other technology. (Lungkhapin, 2013)

6. Focus on the skills of the Twenty first Century.

All activities base on STEM Education can improve the skill in twenty first century such as learning and innovation skills base on the concept of Partnership of Twenty First Century skills that cover Four C : Critical thinking, Communication, Collaboration, and Creativity. (Lungkhapin, 2013) Beside this the learning can let student improve many thing that according to quality development skills in Twenty First Century. Such as, Intelligence :students can understand subject matter, Creative thinking : students can improve of the way of thinking such as analysis, inventive and so on...., Attribute : Students can learn how to work as a group, students can make more useful and powerful convey, how to be leader and also how to take criticize from other. (Siripattrachai, 2013)

7. Building an awareness and participation in the community.

Teacher can take students on fieldtrip around community; also they can explore the local nature environment. Students can learn and report the environmental from local resources to community. Students will learn and solve the problem in the local products. These learning activities will benefits students and community. Also can create an environment, pride and the most importuning, it's build the stronger sense of responsibility in quality education in local occur. (Lungkhapin, 2013)

According to literature of activities for STEM Education, the authors were suggested how to provide the learning activities for physics in order to enhance students to learn physics on the relationship between science, technology, engineering, and mathematics. The 7 STEM guidelines activities (Integrate Science, Technology, Engineering and Mathematics Content; Link all the Science, Mathematics and Technology to real world; Engage in inquiry; Project base; Apply Technology Strategically; Focus on the skills of the Twenty first Century; Building an awareness and participation in the community) will be taken into account for physics leaning on the relationship between science, technology, engineering, and mathematics (STEM). It indicates that Science, Technology, and Society (STS) approach could support all these 7 STEM guidelines activities to provide physics learning activities on the relation between STEM.

STS approach is learning that promotes inquiry scientific knowledge of social issues and technology in community, locality and world. (Yuenyong\&Narjaikaew,2009; Chantaranima,2013) Therefore student will study the problem and also 
questioning on society and technology. Student is also self explanation by involvement of evidences in the communication, concept and reason and the way of comparison in the concept by strong of evidences before the determined of which way is important and not important of learning. It's also integrated in to other study. This is the way of STEM Education work. Beside that the student will do research the science knowledge from the objective in society and technology. Student also make good work and integrated all the knowledge to STEM Education.(Yuenyong, 2006; Klahan and Yuenyong, 2012.)

Beside the knowledge in the Science, Technology and Society also integrated in to other knowledge's that can be approved by the local expert. Also can letting student making project on open - ended problems by student own interest. This is the learning though the uses of real life and the local expert can be the guide line for student. Science, Technology and Society can help student with research, debate by listen to the expert. (Klahan, 2012. Chantaranima, 2013)

\section{Science Technology and Society (STS) Approach of Science Learning}

According to the different and goals of STS there are several ways of attaining, objectives (Aikenhead, 1994). In this research, participants developed the STS unit regarding Yuenyong(2006)'s STS approach. Teaching and learning are started from society realm and moved to acquiring technology, science concepts and skills. Finally, students have chance to take action in society. Yuenyong (2006) developed science unit through STS approach that consisted of five stages including identification of social issues, identification of potential solutions, need for knowledge, decision-making, and socialization stage.

(1) Identification of social issues stage. This stage is designed to focus on student attention and attitudes also learning about Circular motion. The STS instruction begin in the realm of society, social issuerelated to Circular motion. These questions or problems of social issues need to be solved by citizens. For Circular motion concept areCentripetal force and car on a banked curveby various strategies; such as informing situation related these issues by posing on newspaper; posing the social questions related to for students to participate in public decision- making and seeing social problem by taking field trip.

(2) Identification of potential solutions stage. Students plan to solve the social problem related to Circular motion. This stage supports students to concern with technological aspects for find the possible solutions. Technological aspects are skills to support student decision making. Students need to think of what, where, and how ideas, also design, systems, volition of application scientific knowledge work for that social problems. Teaching strategies may be used discussion among students' group, role-play brainstorming, searching information, via internet, and discussion with expert (e.g. engineers or scientists).

(3) Need for knowledge stage. This stage involves developing scientific knowledge. Social questions and technological knowledge can create science content. Circular motion concept was formulated in many strategies to help students to understand the technology and social issues. The strategies, included reflection reading document provided by teacher, and lecture. Students will gain the understanding about projectile motion concept and the short quiz will be taken after class at this stage.

(4) Decision-making stage. This stage with student involves in making a decision on how to use Circular motion knowledge and technology. This aspect public rhetoric about Circular motion related technological and social issues. It's becomes dominates like 'chances and problem', 'advantages and disadvantages', or uses and abuses'. Student will be given chance to learn and choose between alternatives in a thoughtful way systematically comparing as many relevant pro's and con's as possible. Teaching strategies may be used discussion among students' group, role-play, and brainstorming to allow students designing the possible solutions.

(5) Socialization stage. Students need to act as people who are a part of society by reporting their proposal for solving problem. Student might exhibit their solution in public by making poster, write newspaper article or science project (Klahan, 2012).

Summary; an important learning activities based on the concept of Science, Technology and Society (STS) is help to improve students learning behavior in selflearning. Also, focus onproblems in a present situation. The concept of circular motion in which the contents are related to the daily life learners. The physics learning about circular motion would allow students to learn physics on the relation between concepts of science, technology, engineering, and mathematics. Because human lives each day, are related to the phenomenon of movement and things all around. Such as the rotation of the clock and fan, even player at the Theme Park, etc. In the learning subject circular motion of physics, are three learning objectives including (1) can describe the phenomenon, (2) solve problems in daily life and (3) apply to subjects of Engineering, Technologies and Mathematics. 


\subsection{Developing STS Circular motion Unit}

Lesson plans, the concepts based on Circular motion, science, technology and society of Yuenyong (2006) with aiming to students to learn physics on the relation between concepts of science, technology, engineering, and mathematics. It is a step in creating and developing the following:

1. Study Principles, Goals, Visions, Standard measure and indicator. The Content and documents which are related to create a lesson plan follow science courses in the Basic of Education Core Curriculum 2008, in Circular motion of ten grader students.

2. Create a Lesson plan on concept of Science, Technology and Society (STS) by using the STS approach of Yuenyong(2006).

- Identification of social issues stage: on this stage, students must be aware of the social problems due to science and technology, and also grateful that he got involved to help solve the problem.

- Identification of potential solutions stage: students will recognize social problems due to science and technology. At this stage, students will need to answer the problem on planning by the knowledge of their existence and planned to seek additional knowledge that will encourage students to find out the answer.

- $\quad$ Need for knowledge stage : At this stage, students will need to study the scientific knowledge related to the problem.

- Decision-making stage : on this stage, the students will use classroom knowledge to review the guidelines to solving and hand on the problem.

- Socialization stage: Socialization stage, reflected in the students review of concept and out came the problem. At this stage, students will present a scientific exhibition project or campaign.

3. Present the Thesis to advisors.

4. Improve Lesson plans based on the guidance of advisors.

5. Recreated lesson plan, also present the experts for revision.

6. Improve lesson plan based on the recommendations of the experts.

7. Lesson plan use with students who are not the target group.

8. Implement adjust lesson plan for good out come.

9. Implement Lesson plan adjusted to the target group students.

Table 1 :Learning management plan Circular motion through Yuenyong (2006) Science Technology and Society (STS)

\begin{tabular}{|c|l|}
\hline Stage & Activity \\
\hline 1. Identification of social issues stage. & $\begin{array}{l}\text { Students watch video about "Trucks fail to negotiate dangerous bend in road-Brazil". It is a social } \\
\text { issue which relationship with Circular motion. This video there are three trucks fail to negotiate } \\
\text { dangerous bend in road Brazil. }\end{array}$ \\
\hline Identification of potential solutions & $\begin{array}{l}\text { Questions for students : } \\
\text { 1. What did you see on this video and what happen? } \\
\text { 2. If you are engineer?.How you will solve this problem? } \\
\text { Teacher will set the activity, and let the student solve this problem on paper. Student will design a } \\
\text { safetyroad by used scientific knowledge inCircular motion. }\end{array}$ \\
\hline $\begin{array}{l}\text { Students will need to identification of potential solutionson identification of social issues stage } \\
\text { :"Design Safety Road" } \\
\text { First, Students will create questions on knowledge "Design Safety Road" Then each group } \\
\text { brainstorm together to review prior knowledge: "What knowledge can be used to solving the } \\
\text { problem?".Moreover, Students createan unknown knowledge question and further research. }\end{array}$ \\
\hline 3. Need for knowledge stage. & $\begin{array}{l}\text { Teacher set exploration activity and explanations to application for "Design Safety Road"by } \\
\text { Activity 1 : Centripetal force Demonstration. } \\
\text { Teachers swing rope tied to mass. What will happen when teacher release string?. (if string } \\
\text { released when ball here, ball goes straight toward A not toward B,see figure 2) } \\
\text { Teacher and students observe and discuss together about "What will happen when teacher release } \\
\text { string?" which it's related with Centripetal Force. Moreover,it is basic on curve road learning to } \\
\text { "Design Safety Road". }\end{array}$ \\
\hline
\end{tabular}




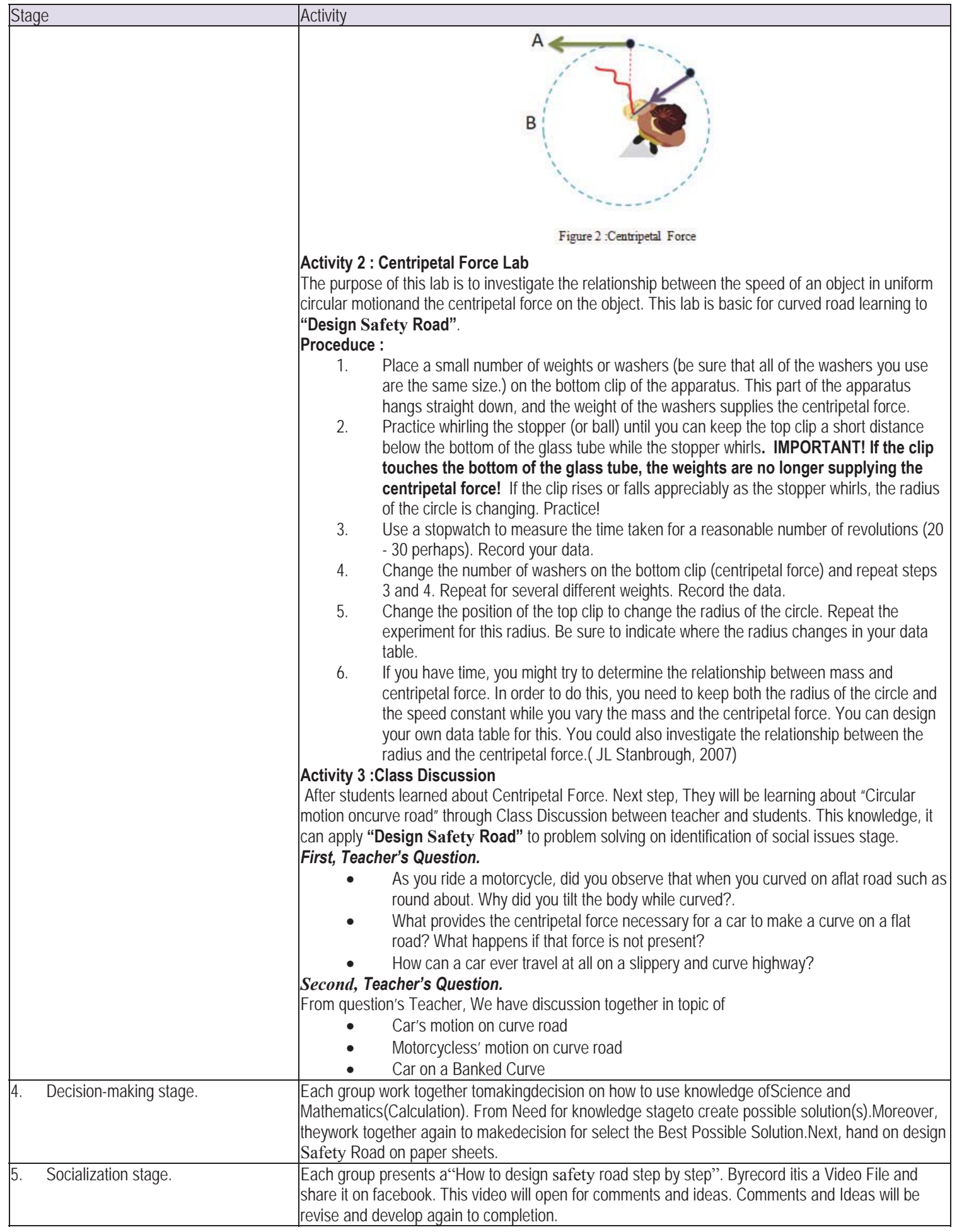

\subsection{STS Circular motion Unit and guideline of relationship between Science Technology Engineering and Mathematics.}

The technology and engineering could be seen as technological process and engineering design, respectively. However, science and mathematics were seen as process, contents and concepts. Therefore, a way of STEM integration may happen between concepts and process of science and mathematics, technological process, and engineering design. Then, the technological process and engineering design would be clarified before we explain how the STS circular motion 
unit provides students to learn physics on the relationship between science, technology, engineering and mathematics.

Technological Process is s process of working to create an artifacts and methods to problemssolving.ISPT (2012) provided technological process in 7 stages. These included: 1) identify the problem, 2) information gathering, 3) selection, 4) design and making, 5) testing, 6) modification and improvement, and 7) assessment.

Engineering design is encourage students to interact with engineering in hands-on activities as a practical application of math and science knowledge. Through actual practice of engineering, they learn that it is not simply building things. Instead, it is a process through which structures are designed, through which clear identification and definition nine of the Identify need or problem, research, planning and brainstorming, testing and evaluation, and Communication are necessary(see Figure3)(Hynes et.al., 2011).

Step 1 :The Identify need or problem.

Step2 :Research the need or problem.

Step 3 :Develop possible solution(s).

Step 4 : Select the Best Possible Solution.

Step 5 :Construct a prototype.

Step 6 : Test and Evaluate the Solution(s).

Step 7 : Communicate the Solution(s).

Step 8 :Redesign.

Step 9 : Completion decision.

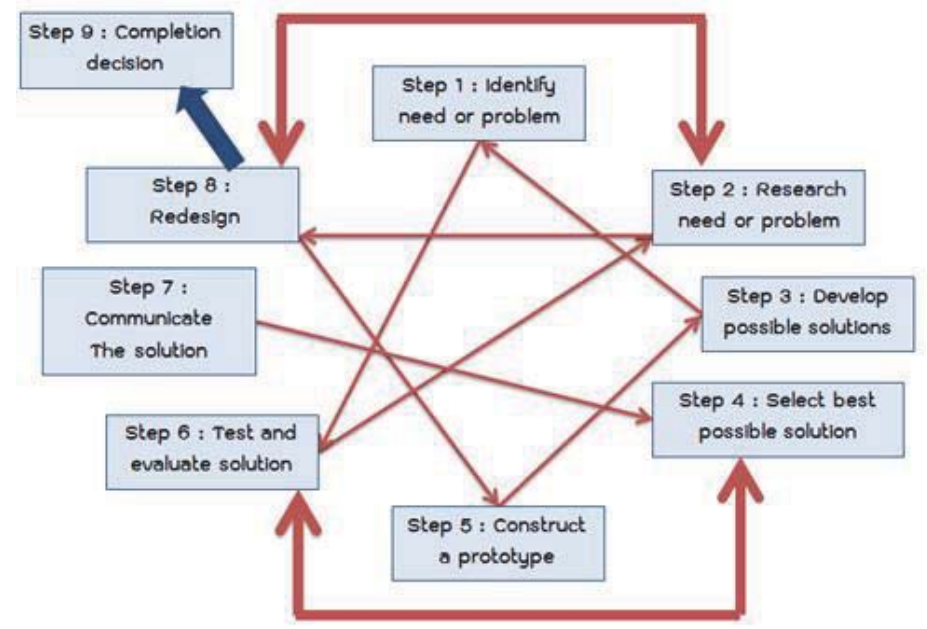

Figure 3: Engineering Design Process

(Morgan Hynes, MerredithPortsmore, Emily Dare, ElissaMilto, Chris Rogers, David Hammer, and Adam Carberry, 2011)

Next, how the STS circular motion unit provides students to learn physics on the relationship between science, technology, engineering and mathematics will be explained. Provided activities in each stage of STS Yuenyong (2006) will be clarified to show possible students learning about concepts and process of science and mathematics, technological process, and engineering design.

First, learning of Circular motion through Yuenyong (2006) Science Technology and Society (STS) on Identification of social issues stage. Social issue use video about "Trucks fail to negotiate dangerous bend in road-Brazil". This social issue, teacher set activity problem. Students will design safety road by used scientific knowledge of Circular motion. In this stage, students will identify problems whichit has consistent with "Engineering Design Process"on step one :the Identify need or problem.

Second, Identification of potential solutions stage, students will create questions on knowledge how use "Design Safety Road". Next step, each group brainstorm together to review prior knowledge: "What knowledge can be used to solving problem?" Moreover, Students create question to unknown knowledges and need further research.

Third, Need for knowledge stage, Students study knowledge of science and mathematics (calculation) involving "Design Safety Road" on a learning resources such as books, magazines, and an internet. Furthermore, Teacher set exploration activity and explanations to apply for "Design Safety Road". 
Activity 1 : Centripetal force Demonstration.

Activity 2 : Centripetal Force Lab

Activity 3 : Class Discussion

Identification of potential solutions stage and Need for knowledge stage have relate with knowledge ofscience(Circular motion) and mathematics(calculation).Moreover, both stage have relate with "Engineering Design Process" on steptwo : research the need or problem.

Forth, Decision-making stage, each group work together in making a decision on how to use knowledge of science and mathematics(calculation) from Need for knowledge stage and create possible solution(s).Moreover, they work together making decision for best possible solution. Next, hand on design Safety Road on paper sheets.

Found that "Decision-making stage" has relate with knowledge of Science(Circular motion), Mathematics (calculation) and Technology (Technological Process)

Moreover, this stagehas relate with "Engineering design" on step 3-5:

- Step three : Develop possible solution(s), each group apply knowledge from Need for knowledge stage to create possible solution(s).

- Step four : Select the Best Possible Solution. This step, each groupwork together in making a decision on select the best possible solution for design Safety Road.

- Step five : Construct a prototype. After select the best possible solution, each group start "Design safety Road" on paper sheets.

Fifth, Socialization stage, This stage, Students need to act as people who are a part of society by reporting their solving problem proposal(Klahan, 2012). Student will exhibit their solution in public that "How to design safety road step by step". By record it is a Video File and share on Facebook. This video will open for comments and ideas. Comments and Ideas will be revise and develop again to completion.

Found that, this stagehas relate with "Engineering design" on step 6-7

- Step six: Test and Evaluate the Solution(s). Students evaluate "Design SafetyRoad" from comments and ideas.

- Step seven: Communicate the Solution(s). There is a video for sharecomments and ideas.

- Step eight: Redesign. Comments and ideas will be revise and develop again to completion for "Design SafetyRoad".

\section{Conclusion}

Development for learning of Circular motion through Yuenyong(2006) Science, Technology and Society approach can promote concept on STEM Education that students will integrate a knowledge between Science (Circular motion), Technology(Technological Process) Engineering(Engineering design) and Mathematics(calculation) through social problem (design safety road). Moreover, we can divide a relationship of Science, Technology, Engineering and Mathematics into 2 groups: (1) Group's skills, abilities and knowledge are Science (Circular motion) and Mathematics (calculation). (2) Group's skills in workflow or process of creating are Technology (Technological Process) Engineering (Engineering design). Finally, found that Engineering design have a relationship with Yuenyong (2006) Science, Technology and Society approach.

\section{Acknowledgements}

The research was financially supported by the institute for the promotion of teaching science and technology (IPST) and the project for the Promotion of Science and Mathematics Talented Teachers (PSMT)

\section{References}

Aikenhead, G. (1994a). What is STS science teaching? In Solomon, J. and Aikenhead, G. (Eds.). (pp.169 - 186). STS Education : International Perspective on Reform. New York, USA: Teachers College Press, Columbia University.

Bernard J. Sadusky. (2012). STEM standards of practice and STEM education definition. Retrieved from www.marylandpublicschools. org/NR/rdonlyres/3ECF0379-2EE9-42AD-A5FC-CA81E8F3FEEA/32260/MarylandStateSTEMStandardsofPractice_.pdf

Bybee, R.W.(2010). Advancing STEM education : A 2020 vision. Technology and Engineering Teacher. 70(1), 30-35.

Chantaranima, T. (2013). The Outcomes of Teaching and Learning About Sound Based on Science Technology and Society (STS) Approach. Science Direct. 116 ( 2014 ), 2286 - 2292. 
DeJarnette, N. K. (2012). America's children: Providing early exposure to STEM (science, technology, engineering and math) initiatives. Education, 133(1), 77-84.

ISPT (2012) Technological Process. Retrieved from www.designtechnology.ipst.ac.th/index.php/?option=com_content\&view= article\&id $=69 \&$ Itemid $=108$

JL Stanbrough. (2007). Physics Lab : Centripetal Force and Speed. Retrieved from http://www.batesville.k12.in.us/physics/phynet/ mechanics/circular\%20motion/labs/cf_and_speed.htm

Klahan, T. and Yuenyong, C. (2012). An analysis of grade 12 students' technological capability in learning about electromagnetics through science technology and society approach (STS approach). Science Direct. 46 ( 2012 ), 5085 - 5093.

Lungkhapin S. (2013). Guidelines and principles of STEM education. Retrieved from www.thailand.intel.com/content/www/th/th/ education/intel-in-education.html

Morgan Hynes, MerredithPortsmore, Emily Dare, ElissaMilto, Chris Rogers, David Hammer, \& Adam Carberry. (2011). Infusing Engineering Design into High School STEM Courses. National Center for Engineering and Technology Education. 165, 8-13.

Siripattrachai, P. (2013). STEM education and 21th century skills development. Executive journal, 33(2), 49-56.

Yuenyong, C.: 2006. Teaching and Learning about Energy : Using STS approach. Bangkok, Thailand : Thesis of Doctoral Degree in Science Education, Kasetsart University.

Yuenyong, C. \&Narjaikaew, P. (2009). Scientific Literacy and Thailand Science Education. International Journal of Environmental and Science Education. 4(3): 335-349. 